Check for updates

Cite this: Chem. Sci., 2019, 10, 4662

๑ All publication charges for this article have been paid for by the Royal Society of Chemistry

Received 6th February 2019

Accepted 18th March 2019

DOI: $10.1039 / c 9 s c 00657 e$

rsc.li/chemical-science

\section{Synthesis of unsymmetrical $B_{2} E_{2}$ and $B_{2} E_{3}$ heterocycles by borylene insertion into boradichalcogeniranes $\uparrow$}

\author{
Siyuan Liu, ${ }^{\text {ab }}$ Marc-André Légaré, (D) ab Alexander Hofmann, ${ }^{\text {ab }}$ Anna Rempel, ${ }^{\text {ab }}$ \\ Stephan Hagspiel ${ }^{\mathrm{ab}}$ and Holger Braunschweig (D) *ab
}

We report the selective insertion of a range of borylene fragments into the $E-E$ bonds $(E=S, S e, T e$ ) of cyclic boron dichalcogenides. This method provides facile synthetic access to a variety of symmetrical and unsymmetrical four- and five-membered rings.

\section{Introduction}

1,3-Dithietanes ${ }^{1}$ - four-membered $\left[\mathrm{C}_{2} \mathrm{~S}_{2}\right]$ cyclic molecules comprise a scarce class of compounds. This, however, is at odds with the fact that the cyclic 1,3-dithietyl moiety is found in bioactive compounds ${ }^{2}$ such as antibacterial ${ }^{2 b}$ and hepatoprotective agents ${ }^{2 c, d}$ and pesticides. ${ }^{2 e}$ Even more rare are the heavier analogues of 1,3-dithietanes, 1,3-diselenetane and 1,3ditelluretane, which typically arise from the dimerization of a handful of selenones and tellurones. ${ }^{3}$ In the main group, Group 13 analogues of these heterocycles are known but remain limited in scope due to a dearth of options for their selective synthesis. ${ }^{4}$

Molecular compounds of aluminium and gallium that feature a central planar $\mathrm{M}_{2} \mathrm{E}_{2}$ ring surrounded by organic substituents may be accessed by reaction of dihydride or dimethyl precursors with elemental chalcogens ${ }^{4 a-f}$ or by double $\sigma$-bond metathesis with $\mathrm{H}_{2} \mathrm{~S}^{4 g}$ or $\mathrm{E}\left(\mathrm{SiMe}_{3}\right)_{2} \cdot{ }^{4 h}$ Recently MoyaCabrera and coworkers succeeded in synthesizing a unique mixed-chalcogen $\mathrm{Al}_{2} \mathrm{OTe}$ ring by step-wise reaction of stoichiometric $\mathrm{H}_{2} \mathrm{O}$ and Te with a $\beta$-diketiminato aluminium dihydride. ${ }^{5}$ In the rather less well-explored area of low-valent Group 13 chemistry Schnöckel et al. synthesized the cyclic compound $\left[(\mu-\mathrm{S}) \operatorname{AlI}\left(\mathrm{NEt}_{3}\right)\right]_{2}$ by oxidizing an $\mathrm{Al}(\mathrm{I})$ iodide precursor with $\mathrm{S}_{8},{ }^{6}$ while Power et al. activated $\mathrm{N}_{2} \mathrm{O}$ and $\mathrm{S}_{8}$ with a $\beta$-diketiminatestabilized $\mathrm{Ga}(\mathrm{I})$ compound to yield the corresponding gallium oxide and sulfide dimers. ${ }^{7}$ For boron, strained diamino- $\mathrm{B}_{2} \mathrm{E}_{2}$ rings were obtained by Forstner and Muetterties from the reaction of $\mathrm{B}\left(\mathrm{NEt}_{2}\right)_{3}$ with $\mathrm{H}_{2} \mathrm{~S},{ }^{8}$ and later by Nöth through thermolysis or photolysis of the $[2+2]$ cycloaddition products of

Institut für Anorganische Chemie, Julius-Maximilians-Universität Würzburg, Am Hubland, 97074 Würzburg, Germany. E-mail: h.braunschweig@uni-wuerzburg.de

${ }^{b}$ Institute for Sustainable Chemistry \& Catalysis with Boron, Julius-MaximiliansUniversität Würzburg, Am Hubland, 97074 Würzburg, Germany

$\dagger$ Electronic supplementary information (ESI) available. CCDC 1886448-1886454. For ESI and crystallographic data in CIF or other electronic format see DOI: 10.1039/c9sc00657e
$\mathrm{E}=\mathrm{C}=\mathrm{E}(\mathrm{E}=\mathrm{O}, \mathrm{S}, \mathrm{Se})$ with a bulky iminoborane..$^{9}$ Interestingly, while a theoretical investigation led by Marder identified crucial factors for the rarity of $\mathrm{B}_{2} \mathrm{O}_{2}$ rings, ${ }^{9 c}$ such cyclic compounds can be formed by the hydrolysis of haloboron complexes, ${ }^{9 c, d}$ the dimerization of diboroxanes ${ }^{9 e}$ and, by the controlled dimerization of a platinum oxoboryl complex. ${ }^{9 f}$ Indeed, the chemistry of $\mathrm{B}-\mathrm{O}$ heterocycles is predominantly the field of six-membered boroxine $\left(\mathrm{B}_{3} \mathrm{O}_{3}\right)$ rings.

More recently, our group reported the convergent reactivity of low-valent boron species $([(\mathrm{CAAC})(\mathrm{NC}) \mathrm{B}=\mathrm{B}(\mathrm{CN})(\mathrm{CAAC})](\mathrm{CAAC}=$ 1-(2,6-diisopropylphenyl)-3,3,5,5-tetramethylpyrrolidin-2-ylidene) and $\left.c y c l o-[(\mathrm{CAAC}) \mathrm{B}(\mu-\mathrm{CN})]_{4}\right)$ with sulfur and selenium to give, among other products, $\left[\text { cyclo- }(\mathrm{CAAC}(\mathrm{NC}) \mathrm{B}(\mu-\mathrm{S}))_{2}\right]^{10}{ }^{10}$ The outcome of the reaction is highly dependent on the stoichiometry of the reagents used, yielding larger and smaller rings when different amounts of chalcogen were employed. We have also observed the slow, yet selective, dimerization of monomeric, N-heterocyclic carbene (NHC)-stabilized borachalcones $[\mathrm{IMe}(t \mathrm{Bu}) \mathrm{B}=\mathrm{E}](\mathrm{IMe}=$ dimethylimidazolylidene; $\mathrm{E}=\mathrm{S}$, Se) into four-membered heterocycles. ${ }^{11}$ To our knowledge, however, unsymmetrically substituted four- and five-membered cyclic chalcogenides of boron are yet to be reported.

We have recently reported the reactivity of the N-heterocycliccarbene-stabilized manganese borylene complex $\left[\mathrm{Cp}(\mathrm{OC})_{2} \mathrm{Mn}=\right.$ $\mathrm{B} t \mathrm{Bu}(\mathrm{IMe})]^{12 b}$ with chalcogens (S, Se, Te) ${ }^{13}$ selectively affording a range of unusual boron chalcogenides, including a family of novel free and metal-bound boradichalcogenanes $\left(\left[\mathrm{Cp}(\mathrm{OC})_{2} \mathrm{Mn}\right.\right.$ $\left.\left\{\kappa^{1}-c y c l o-\mathrm{TeTeB}(t \mathrm{Bu})(\mathrm{IMe})\right\}\right](\mathbf{1})$ and $[c y c l o-\mathrm{EEB} t \mathrm{Bu}(\mathrm{IMe})](\mathrm{E}=\mathrm{Se}$ (2a), $\mathrm{S}(\mathbf{2 b}))) .{ }^{11}$ We now report that these complexes selectively react with a number of different transition metal borylene complexes to afford a range of unsymmetrically substituted $\mathrm{B}_{2} \mathrm{E}_{2}$ four-membered rings under mild conditions (Fig. 1).

\section{Results and discussion}

Borylene complexes of the group VI metals figure among the most studied metal-stabilized sources of borylene fragments. ${ }^{14}$ 
Preparation of boradichalcogeniranes used in this study:

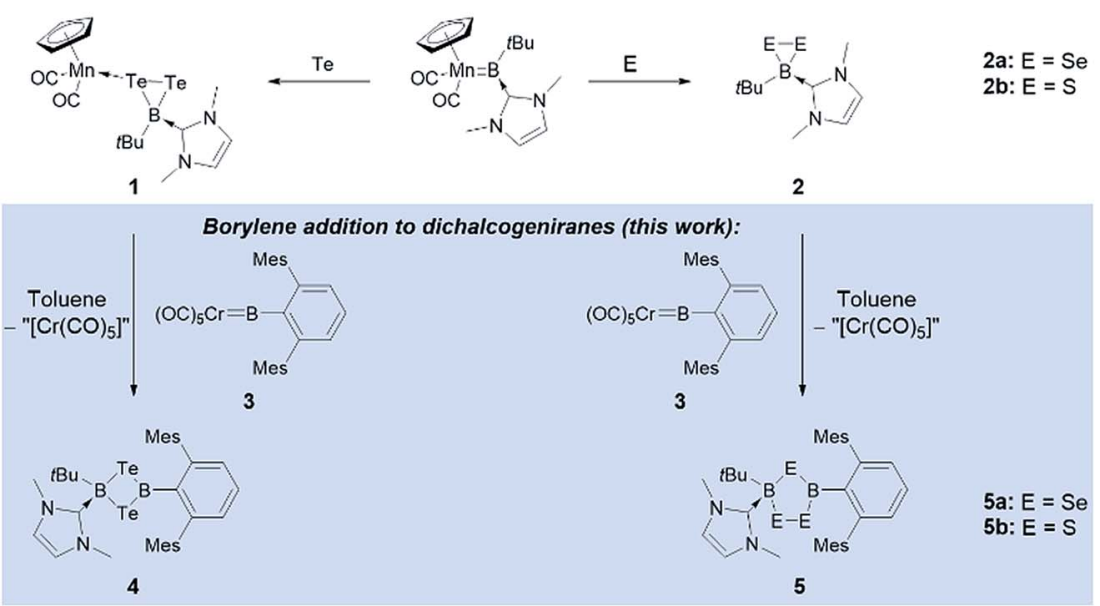

Fig. 1 Synthesis of boradichalcogeniranes (and a manganese adduct thereof) from a manganese borylene complex, and reaction of these chalcogenides with chromium borylene complex 3 .

In recent years, borylene complexes of chromium, molybdenum and tungsten have been shown to engage in metal-tometal, ${ }^{14 h, i, n, o}$ metal-to-carbon ${ }^{14 g, j}$ and metal-to-nitrogen ${ }^{14 k}$ borylene transfer, in $\mathrm{C}-\mathrm{H}$ activation ${ }^{14 l}$ and in $[2+1]$ addition reactions. ${ }^{14 m}$ Towards our study of the reactivity of boradichalcogeniranes with low-valent boron fragments, the sterically protected borylene complex $\left[(\mathrm{OC})_{5} \mathrm{Cr}=\mathrm{BTp}\right](3)(\mathrm{Tp}=$ 2,6-bis(2,4,6-trimethylphenyl)phenyl) was deemed a good starting point. Treatment of boraditellurirane complex 1 with one equivalent of 3 in toluene allowed us to isolate cyclo[(tBu)(IMe)B-Te-B(Tp)-Te] (4) after recrystallization from a toluene/pentane mixture (yield: $24 \%$ ). High-resolution mass spectrometry (HRMS) and single-crystal X-ray diffraction analysis allowed us to identify 4 as an NHC-stabilized 1,3-ditellura2,4-diboretane arising from the insertion of a [BTp] fragment into the Te-Te bond of $\mathbf{1}$. To the best of our knowledge, 4 represents the first example of such a four-membered $\mathrm{B}_{2} \mathrm{Te}_{2}$ ring (Fig. 2).

This new species features two resonances in its ${ }^{11} \mathrm{~B}$ NMR spectrum $(\delta=-33.0$ and 61.1) which differ considerably from those of both starting materials ( $\delta=-2.0(1)$ and 147 (3)), as expected for its unsymmetrical substitution pattern. The new signal at $-33.0 \mathrm{ppm}$ is attributable to the $\mathrm{sp}^{3}$-hybridized tetrahedral boron atom that is coordinated by an IMe ligand (B2), while the peak at $61.1 \mathrm{ppm}$ can be assigned to the BTp moiety. In the solid state, $\mathbf{4}$ features a near-planar four-membered cycle which is close to perpendicular with the CBC plane of the $(t \mathrm{Bu})$ $\mathrm{B} 2(\mathrm{IMe})$ group. The Tp substituent is rotated approximatively $15^{\circ}$ from perpendicularity with the $\mathrm{B}_{2} \mathrm{E}_{2}$ cycle. Interestingly, the $\mathrm{B}-\mathrm{Te}$ distances are different for both boron centers. Indeed, the TpB1-Te bonds are significantly shorter (2.153(2) and 2.139(2) $\AA$ ) than the corresponding $t \mathrm{Bu}(\mathrm{IMe}) \mathrm{B} 2-\mathrm{Te}$ distances (2.358(2) and 2.331(2) $\AA$ ), likely owing to Te-to-B $\pi$-donation, which is not present in the case of the $\mathrm{sp}^{3}$-hybridized $\mathrm{B} 2$.

Borylene complex 3 was also reacted with the Se and S compounds $\mathbf{2 a}$ and $\mathbf{2 b}$ under the same conditions as for $\mathbf{1}$.
Interestingly, in these cases the Se and $\mathrm{S}$ analogs of the fourmembered $\mathrm{B}_{2} \mathrm{Te}_{2}$ compound 4 were only observed as minor products, which we were unable to isolate, however we were able to obtain a few crystals of the selenium-containing analog of $\mathbf{4}$, which allowed us to determine a solid-state structure and
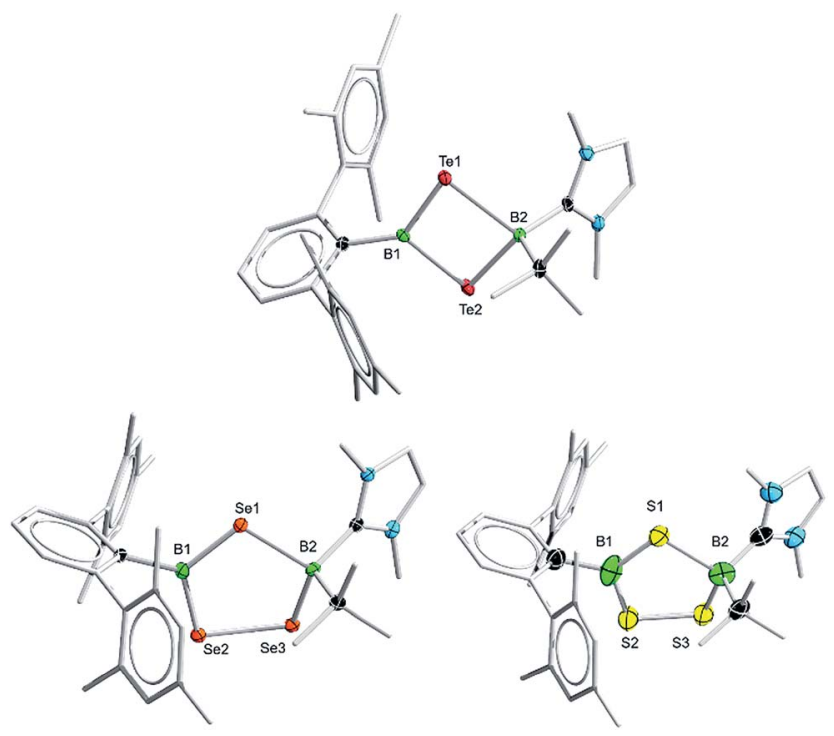

Fig. 2 POV-Ray depictions of the crystallographically determined structures of compounds 4 (top), 5a (bottom left) and 5b (bottom right). Atomic displacement ellipsoids depicted at the $50 \%$ probability level. Hydrogen atoms and ellipsoids of peripheral groups omitted for clarity. Selected bond distances (Å) and angles ( $\left.{ }^{\circ}\right)$ : 4: B1-C(Tp) 1.569(3), $\mathrm{B} 1-\mathrm{Te} 12.153(2), \mathrm{B} 1-\mathrm{Te} 2$ 2.139(2), B2-C(tBu) 1.637(4), B2-C(IMe) 1.624(3), B2-Te1 2.358(2), B2-Te2 2.331(2), Te1-B1-Te2 102.7(1), B1Te1-B2 82.38(9), Te1-B2-Te2 91.23(9), B1-Te2-B2 83.33(9); 5a: B1$C(T p)$ 1.585(5), B1-Se1 1.919(5), B1-Se2 1.921(4), B2-C(tBu) 1.641(7), $\mathrm{B} 2-\mathrm{C}(\mathrm{IMe})$ 1.630(7), B2-Se1 2.115(4), B2-Se3 2.106(4), Se1-B1-Se2 119.4(3), C(Tp)-B1-Se1 120.3(3), C(Tp)-B1-Se2 120.2(3), C(tBu)-B1$\mathrm{C}(\mathrm{IMe})$ 112.7(3), Se1-B1-Se3 105.4(2), B2-Se3-Se2 102.7(1), Se3Se2-B1 100.7(2), B1-Se1-B2 105.5(2). 
confirm its connectivity (see ESI $\dagger$ ). In these reactions, after crystallization from a $\mathrm{THF} /$ pentane mixture, the fivemembered rings cyclo-[(tBu)(IMe)B-EE-B(Tp)-E] (E = Se (5a) and $S(5 \mathbf{b})$ ) were obtained (yield $22 \%$ in both cases). In the 1,2,4-triselena-3,5-diborolane 5a, the ${ }^{11} \mathrm{~B}$ NMR signals for the two boron atoms were found at 6.2 and $72.1 \mathrm{ppm}$. Similarly, in $\mathbf{5 b}$, they are found at 7.7 and $66.2 \mathrm{ppm}$. The five-membered rings $\mathbf{5 a}$ and $\mathbf{5 b}$ are likely to arise from the initial formation of Se and $S$ analogues of 4 , which then undergo ring expansion using the starting materials or reaction intermediates as sacrificial chalcogen sources. While ${ }^{11} \mathrm{~B}$ NMR monitoring of the reaction showed the formation of other boron chalcogenide species - as is predicted from the stoichiometry of the reaction - these byproducts could not be identified. $\mathbf{5 a}$ and $\mathbf{5 b}$ can however be reliably crystallized from the reaction mixture and isolated.

In the solid state, $\mathbf{5 a}$ is structurally comparable to the three previously reported examples of crystallographically characterized BSeBSeSe non-cluster five-membered rings. ${ }^{15}$ Interestingly, it represents, to our knowledge, the first example of such a cycle with an unsymmetrical substitution pattern. The planar $\mathrm{sp}^{2}$-hybridized $\mathrm{TpB}$ site features $\mathrm{B}-\mathrm{Se}$ distances (1.919(5) and 1.921(4) §) that are close to those reported by Tokitoh and coworkers in a symmetrical five-membered ring of selenium and $\mathrm{sp}^{2}$ boron. ${ }^{15 b}$ In contrast, on the $t \mathrm{Bu}(\mathrm{IMe}) \mathrm{B}$ side of 5a, the B-Se distances (2.115(4) and 2.106(4) $\AA$ ) are analogous to those found in triselena-1,3-diborolanes with $\mathrm{sp}^{3}$ boron atoms. ${ }^{10,15 c}$ Unfortunately, while we were able to grow crystals of $\mathbf{5 b}$, their poor quality, combined with the absence of heavy elements, did not yield crystallographic data of a precision that would allow us to discuss structural parameters. Instead, the single-crystal X-ray diffraction analysis only allows us to confirm the connectivity and the substitution pattern in the molecule.

Since the insertion of TpB fragments into $\mathbf{2 a}$ and $\mathbf{2 b}$ did not allow us to selectively synthesize unsymmetrical B-Se dichalcogenadiboretane rings, we elected to react these precursors with other borylene sources. Thus, the Group 6 aminoborylene complex $\left[(\mathrm{OC})_{5} \mathrm{Mo}=\mathrm{BN}\left(\mathrm{SiMe}_{3}\right)_{2}\right](\mathbf{6})$ was reacted with $\mathbf{2 a}$ and $\mathbf{2 b}$ in toluene. In both cases, four-membered cyclic products, cyclo$\left[(t \mathrm{Bu})(\mathrm{IMe}) \mathrm{B}-\mathrm{E}-\mathrm{B}\left\{\mathrm{N}\left(\mathrm{SiMe}_{3}\right)_{2}\right\}-\mathrm{E}\right](\mathrm{E}=\mathrm{Se}(\mathbf{7 a})$ and $\mathrm{S}(7 \mathbf{b}))$, were obtained after recrystallization from a toluene/pentane mixture (yield: $52 \%$ (7a) and $38 \%$ (7b)). The possibility of ring expansion processes (vide supra), combined with the difficulties in quantitatively crystallizing these products, explains the moderate yields of the reactions.

In $7 \mathrm{a},{ }^{11} \mathrm{~B}$ NMR signals at -13.4 and $46.7 \mathrm{ppm}$ can be assigned to the $\mathrm{sp}^{3}$ and $\mathrm{sp}^{2}$ boron centers, respectively. In the solid state, the 1,3-diselena-2,4-diboretane cycle is nearly planar, as in the case of 4. A slight pyramidalization of the $\mathrm{N}\left(\mathrm{SiMe}_{3}\right)_{2}$ group, as well as dihedral angles of $c a .35^{\circ}$ between this group and the $\mathrm{B}_{2} \mathrm{Se}_{2}$ and a B-N bond distance of 1.442(7) $\AA$ (longer than 1.3549(18) $\AA$ in 6), suggest only a small amount of $\mathrm{N}$-to-B $\pi$-donation. Consistent with this observation, the $\left(\mathrm{Me}_{3}\right.$ $\mathrm{Si})_{2} \mathrm{NB}-$ Se bond distances (1.957(5) and 1.958(5) $\mathrm{A}$ ), while being longer than in $\mathbf{5 a}$, are short enough to suggest some Se-to-B $\pi$ donation competing with the $\mathrm{N}-\mathrm{B}$ multiple bonding. On the
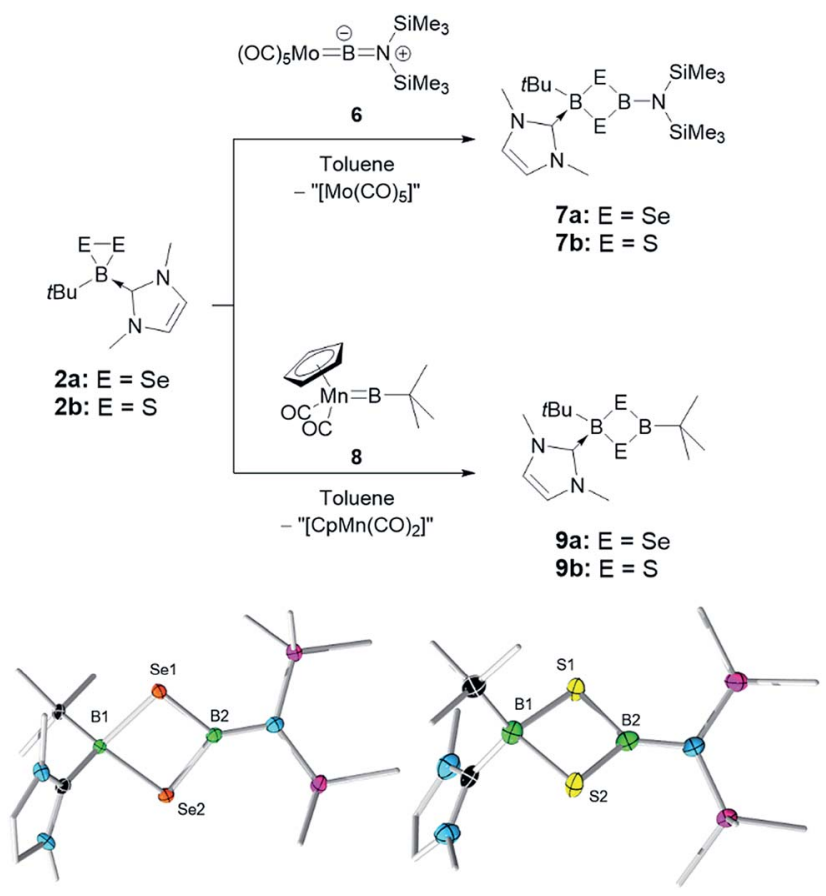

Fig. 3 Reactions of boradichalcogeniranes $2 \mathrm{a}$ and $2 \mathrm{~b}$ with borylene complexes 6 and 8 (top). POV-Ray depictions of the crystallographically determined structures of compounds $7 \mathrm{a}$ (bottom left) and $7 \mathrm{~b}$ (bottom right). Atomic displacement ellipsoids depicted at 50\% probability level. Hydrogen atoms and ellipsoids of peripheral groups omitted for clarity. Selected bond distances $(\AA \AA)$ and angles $\left({ }^{\circ}\right)$ : 7a: B1$\mathrm{C}(\mathrm{tBu})$ 1.628(6), B1-C(IMe) 1.631(6), B1-Se1 2.116(5), B1-Se2 2.112(5), $B 2-N$ 1.442(7), B2-Se1 1.957(5), B2-Se2 1.958(5), B1-Se1-B2 81.7(2), Se1-B2-Se2 102.9(2), B2-Se2-B1 81.8(2), Se2-B1-Se1 92.8(2); 7b: $\mathrm{B} 1-\mathrm{C}(\mathrm{tBu})$ 1.632(5), B1-C(IMe) 1.633(5), B1-S1 1.998(4), B1-S2 $1.990(3), B 2-N$ 1.440(5), B2-S1 1.855(3), B2-S2 1.844(4), B1-S1-B2 80.8(2), S1-B2-S2 104.0(2), B2-S2-B1 81.2(2), S2-B1-S1 94.0(2).

other side of the molecule, the $(t \mathrm{Bu})(\mathrm{IMe}) \mathrm{B}-\mathrm{Se}$ distances (2.112(5) and 2.116(5) $\AA$ ) are considerably longer, consistent with the presence of an $\mathrm{sp}^{3}$ boron center. In the case of $7 \mathbf{b},{ }^{11} \mathrm{~B}$ NMR signals were found at -6.1 and $49.8 \mathrm{ppm}$. The solid-state structure of $\mathbf{7 b}$ is comparable to that of $7 \mathbf{a}$, with $\left(\mathrm{Me}_{3} \mathrm{Si}\right)_{2} \mathrm{NB}-\mathrm{S}$ bond distances of 1.844(4) and 1.855(3) $\AA$, $t \mathrm{Bu}(\mathrm{IMe}) \mathrm{B}-\mathrm{S}$ distances of 1.990(3) and 1.998(4) $\AA$ and a B-N bond measuring 1.440(5) ^̊ (Fig. 3).

$2 \mathbf{a}$ and $\mathbf{2 b}$ also react with $\left[\mathrm{Cp}(\mathrm{OC})_{2} \mathrm{Mn}=\mathrm{B} t \mathrm{Bu}\right](\mathrm{Cp}=$ cyclopentadienyl) (8), ${ }^{12 a}$ a manganese borylene complex that has a rich reactivity ${ }^{12}$ and that is a precursor of $\mathbf{1}, \mathbf{2 a}$ and $2 \mathbf{b}$. While we were not able to obtain high-quality crystals from this reaction, HRMS of the isolated products revealed a formula consistent with cyclo- $[(t \mathrm{Bu})(\mathrm{IMe}) \mathrm{B}-\mathrm{E}-\mathrm{B}(t \mathrm{Bu})-\mathrm{E}](\mathrm{E}=\mathrm{Se}(\mathbf{9 a})$ and $\mathrm{S}$ (9b)), arising once again from the transfer of a borylene fragment $(t \mathrm{BuB})$ from 8 to $2 \mathbf{a}$ and $\mathbf{2 b}$. The solution ${ }^{1} \mathrm{H}$ and ${ }^{13} \mathrm{C}$ NMR spectra of $\mathbf{9 a}$ and $\mathbf{9 b}$ are consistent with the formula assignment from HRMS, revealing a $1: 1: 1$ ratio of IMe and two inequivalent $t \mathrm{Bu}$ groups. The ${ }^{11} \mathrm{~B}$ NMR resonances of $9 \mathrm{a}(\delta=$ -10.8 and 77.5$)$ and $9 \mathbf{b}(\delta=-3.6$ and 72.9$)$ reveal a similar environment for the $\mathrm{sp}^{3}$ boron atom as that in the corresponding four-membered rings $7 \mathbf{a}$ and $\mathbf{7 b}$, which leads us to 
postulate that products $\mathbf{9 a}$ and $\mathbf{9 b}$ are indeed the cyclic compounds cyclo-[( $t \mathrm{Bu})(\mathrm{IMe}) \mathrm{B}-\mathrm{E}-\mathrm{B}(t \mathrm{Bu})-\mathrm{E}]$.

Finally, 2a was also found to react with the macrocyclic complex cyclo- $[(\mathrm{CAAC}) \mathrm{BCN}]_{4}(\mathbf{1 0}) .{ }^{16}$ This metal-free tetrameric borylene was previously shown to be a useful source of the corresponding monomer [(CAAC)BCN] in its reaction with Lewis bases and to generate of one of the few reported examples of cyclo-[BSe $]_{2}$ complexes by reaction with elemental selenium. Thus, the reaction of $\mathbf{2}$ and $\mathbf{1 0}$ in toluene led to the isolation of the new 1,3-diselena-2,4-diborolane cyclo-[( $t \mathrm{Bu})(\mathrm{IMe}) \mathrm{B}-\mathrm{Se}-$ $\mathrm{B}(\mathrm{CAAC}) \mathrm{CN}-\mathrm{Se}]$ (11) in a $34 \%$ yield. While once again unsymmetrically substituted, this compound is the first of the series reported herein to feature two $\mathrm{sp}^{3}$-hybridized boron atoms. The ${ }^{11} \mathrm{~B}$ NMR spectrum of 11 shows two signals at -9.5 and $-32.8 \mathrm{ppm}$. While both signals lie within the typical range for $\mathrm{sp}^{3}$ boron atoms, we can assign the former to the $(t \mathrm{Bu})(\mathrm{IMe}) \mathrm{B}$ group by comparison to $7 \mathbf{a}$ and $\mathbf{9 a}$, while the latter is similar to the signals of both isomers of the previously reported cyclo$[(\mathrm{CAAC})(\mathrm{CN}) \mathrm{B}-\mathrm{S}-\mathrm{B}(\mathrm{CN})(\mathrm{CAAC})-\mathrm{S}](\delta=-31.8$ and $-33.5 \mathrm{ppm}){ }^{{ }^{10}}$

Rather surprisingly, and in contrast with other 1,3-diselena2,4-diboretes, ${ }^{\mathbf{9 b}, \mathbf{1 0}} \mathbf{1 1}$ adopts a clearly bent butterfly structure in the solid state. This situation is plausibly a consequence of the unsymmetrical substitution pattern, which gives rise to a large difference in steric bulk on both faces of the cycle. The B-Se distances are slightly shorter on the (CAAC)(NC)B side (2.067(1) and $2.079(2) \AA)$ than around the $(t \mathrm{Bu})(\mathrm{IMe}) \mathrm{B}$ moiety $(2.114(1)$ and 2.114(2) @) (Fig. 4).

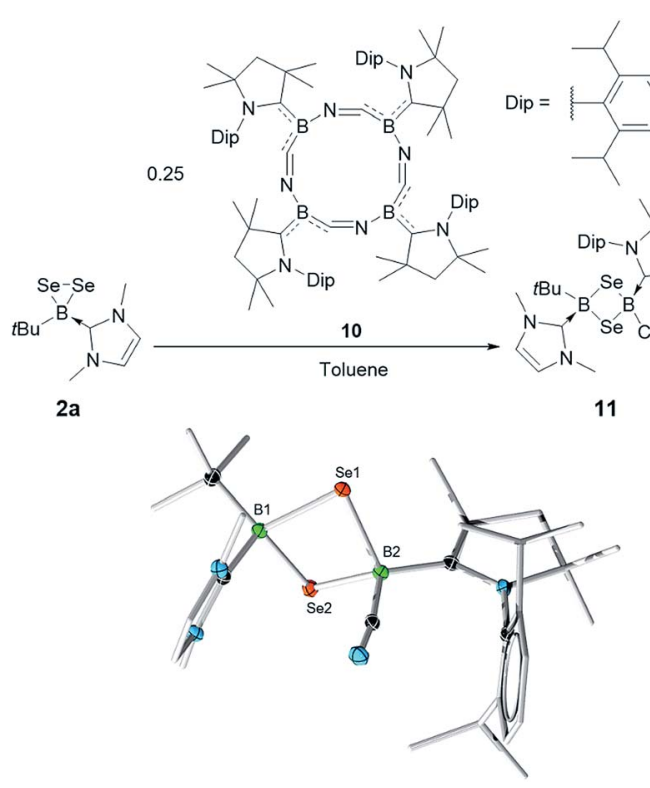

Fig. 4 Preparation and POV-Ray depiction of the crystallographically determined structure of 11 . Atomic displacement ellipsoids depicted at $50 \%$ probability level. Hydrogen atoms and ellipsoids of peripheral groups omitted for clarity. Selected bond distances $(\AA)$ and angles $\left({ }^{\circ}\right)$ : $\mathrm{B} 1-\mathrm{C}(\mathrm{tBu})$ 1.633(9), B1-C(IMe) 1.647(8), B1-Se1 2.113(5), B1-Se2 2.111(7), B2-C(CN) 1.591(9), B2-C(CAAC) 1.602(8), B2-Se1 2.079(7), B2-Se2 2.068(6), B1-Se1-B2 80.4(2), Se1-B2-Se2 96.1(3), B2-Se2B1 80.7(2), Se2-B1-Se1 93.8(3), C(CN)-B2-B(CAAC) 117.9(5), C(tBu)$\mathrm{B} 1-\mathrm{C}(\mathrm{IMe})$ 114.0(5).

\section{Conclusions}

In conclusion, we demonstrate that borylene fragments can be inserted into the $\mathrm{E}-\mathrm{E}$ bonds $(\mathrm{E}=\mathrm{Te}$, Se and $\mathrm{S})$ of boradichalcogeniranes. This reaction gives unprecedented synthetic access to unsymmetrically substituted 1,3-dichalcogena-2,4diboretes and 1,2,4-dichalcogena-3,5-diborolanes. We have thus reported the synthesis of heterocycles featuring unsymmetrical boron centers in $\mathrm{sp}^{2}-\mathrm{sp}^{3}$ and $\mathrm{sp}^{3}-\mathrm{sp}^{3}$ hybridization combinations. Given the lack of methods for the synthesis of such unsymmetrical compounds, this approach will provide us with a useful platform to study the properties and applications of these unusual heterocycles.

\section{Conflicts of interest}

There are no conflicts to declare.

\section{Acknowledgements}

The authors gratefully acknowledge financial assistance from the Deutsche Forschungsgemeinschaft. S. Liu thanks the China Scholarship Council for a Ph.D. Scholarship. M.-A. L. acknowledges the Natural Science and Engineering Research Council of Canada for a postdoctoral fellowship.

\section{Notes and references}

1 (a) A. Behr, Chem. Ber., 1872, 5, 970; (b) A. M. Jeffrey, K. W. Jennette, S. H. Blobstein, I. B. Weinstein, F. A. Beland, R. G. Harvey, H. Kasai, I. Miura and K. Nakanishi, J. Am. Chem. Soc., 1976, 98, 5715-5717; (c) G. Frenking and S. Shaik, The Chemical Bond: Fundamental Aspects of Chemical Bonding, Wiley, 2014.

2 (a) J. G. Contreras and S. T. Madariaga, Bioorg. Chem., 2001, 29, 57-64; (b) N. Nagano, K. Nakano and R. Hara, J. Antibiot., 1991, 44, 415-421; (c) S. G. Kim, Y. J. Suhr and J. A. Miller, Carcinogen, 1998, 19, 687-690; (d) Y. J. Surh, M. Shlyankevich, J. W. Yoo and J. K. Yoo, Mutat. Res., 1996, 367, 219-224; (e) R. W. Addor, J. Heterocycl. Chem., 1970, 7, 381-387.

3 (a) A. Haas, J. Fluorine Chem., 1986, 32, 415-439; (b) R. J. Adrien, R. W. Gable, B. F. Hoskin and D. Dakternieks, J. Organomet. Chem., 1989, 359, 33-39; (c) R. Boese, A. Haas and C. Limberg, J. Chem. Soc., Chem. Commun., 1991, 1378-1379.

4 (a) C. Cui, H. W. Roesky, M. Noltemeyer and H.-G. Schmidt, Organometallics, 1999, 18, 5120-5123; (b) K. S. Klimek, J. Prust, H. W. Roesky, M. Noltemeyer and H.-G. Schmidt, Organometallics, 2001, 20, 2047-2051; (c) W. J. Grigsby, C. L. Raston, V.-A. Tolhurst, B. W. Skelton and A. H. White, J. Chem. Soc., Dalton Trans., 1998, 2547-2556; (d) Y. Peng, H. Hao, V. Jancik, H. W. Roesky, R. Herbst-Irmer and J. Magull, Dalton Trans., 2004, 3548-3551; (e) H. Zhu, J. Chai, H. W. Roesky, M. Noltemeyer, H.-G. Schmidt, D. Vidovic and J. Magull, Eur. J. Inorg. Chem., 2003, 31133119; (f) V. Jancik, M. M. Moya Cabrera, H. W. Roesky, 
R. Herbst-Irmer, D. Neculai, A. M. Neculai, M. Noltemeyer and H.-G. Schmidt, Eur. J. Inorg. Chem., 2004, 3508-3512; (g) C. Schnitter, A. Klemp, H. W. Roesky, H.-G. Schmidt, C. Röpken, R. Herbst-Irmer and M. Noltemeyer, Eur. J. Inorg. Chem., 1998, 2033-2039; (h) R. J. Wehmschulte and P. P. Power, Chem. Commun., 1998, 335-336.

5 S. González-Gallardo, A. S. Cruz-Zavala, V. Jancik, F. CortésGuzmán and M. M. Moya-Cabrera, Inorg. Chem., 2013, 52, 2793-2795.

6 A. Ecker, R. Köppe, C. Üffing and H. Schnöckel, Z. Anorg. Allg. Chem., 1998, 624, 817-822.

7 N. J. Hardman and P. P. Power, Inorg. Chem., 2001, 40, 24742475.

8 (a) J. A. Forstner and E. L. Muetterties, Inorg. Chem., 1966, 5, 164; (b) G. W. Bushnel and G. A. Rivett, Can. J. Chem., 1977, 55, 3294-3297.

9 (a) D. Mannig, C. K. Narula, H. Nöth and U. Wietelmann, Chem. Ber., 1985, 118, 3748-3758; (b) E. Hanecker, H. Nöth and U. Wietelmann, Chem. Ber., 1986, 119, 1904-1910; (c) J. M. Burke, M. A. Fox, A. E. Goeta, A. K. Hugues and T. D. Marder, Chem. Commun., 2000, 2217-2218; (d) T. Wang, S. Kohrt, C. G. Daniliuc, G. Kehr and G. Erker, Org. Biomol. Chem., 2017, 15, 6223-6232; (e) H. Borrmann, A. Simon and H. Vahrenkamp, Angew. Chem., Int. Ed. Engl., 1989, 28, 180-181; (f) H. Braunschweig, K. Radacki and A. Schneider, Angew. Chem., Int. Ed., 2010, 49, 5993-5996.

10 D. Auerhammer, M. Arrowsmith, R. D. Dewhurst, T. Kupfer and H. Braunschweig, Chem. Sci., 2018, 9, 2252-2260.

11 S. Liu, M.-A. Légaré, A. Hofmann and H. Braunschweig, J. Am. Chem. Soc., 2018, 140, 11223-11226.

12 (a) H. Braunschweig, M. Burzler, T. Kupfer, K. Radacki and F. Seeler, Angew. Chem., Int. Ed., 2007, 46, 7785-7787; (b) H. Braunschweig, W. C. Ewing, K. Ferkinghoff, A. Hermann, T. Kramer, R. Shang, E. Siedler and C. Werner, Chem. Commun., 2015, 51, 13032-13035; (c) H. Braunschweig, M. Burzler, T. Kupfer, K. Radacki and F. Seeler, Angew. Chem., Int. Ed., 2007, 46, 8071-8073.

13 S. Liu, M.-A. Légaré, D. Auerhammer, A. Hofmann and H. Braunschweig, Angew. Chem., Int. Ed., 2017, 56, 1576015762.

14 (a) B. Blank, M. Colling-Hendelkens, C. Kollann, K. Radacki, D. Rais, K. Uttinger, G. R. Whittell and H. Braunschweig,
Chem.-Eur. J., 2007, 13, 4770-4781; (b) H. Braunschweig, C. Kollann and U. Englert, Angew. Chem., Int. Ed., 1998, 37, 3179-3180; (c) H. Braunschweig, C. Kollann and D. Rais, Angew. Chem., 2006, 118, 5380-5400; (d) H. Braunschweig, K. Radacki, K. Kraft and S. Stellwag, Z. Naturforsch., B: J. Chem. Sci., 2010, 65, 1073-1076; (e) H. Braunschweig, R. D. Dewhurst and A. Schneider, Chem. Rev., 2010, 110, 3924-3957; (f) H. Braunschweig, R. D. Dewhurst and V. H. Gessner, Chem. Soc. Rev., 2013, 42, 3197-3208; $(g)$ H. Braunschweig, R. D. Dewhurst, F. Hupp, M. Nutz, K. Radacki, C. W. Tate, A. Vargas and Q. Ye, Nature, 2015, 522, 327-330; (h) H. Braunschweig, Q. Ye, K. Radacki and A. Damme, Angew. Chem., Int. Ed., 2012, 51, 7839-7842; (i) H. Braunschweig, Q. Ye, A. Vargas, R. D. Dewhurst, K. Radacki and A. Damme, Nat. Chem., 2012, 4, 563-567; (j) M. Nutz, B. Borthakur, C. Pranckevicius, R. D. Dewhurst, M. Schäffer, T. Dellermann, F. Glaab, M. Thaler, A. K. Phukan and H. Braunschweig, Chem.-Eur. J., 2018, 24, 6843-6847; (k) M. Nutz, B. Borthakur, R. D. Dewhurst, A. Deißenberger, T. Dellermann, M. Schäfer, I. Krummenacher, A. K. Phukan and H. Braunschweig, Angew. Chem., Int. Ed., 2017, 56, 79757979; ( $l$ ) H. Braunchweig, R. D. Dewhurst, T. Herbst and R. Radacki, Angew. Chem., Int. Ed., 2008, 47, 5978-5980; (m) H. Braunchweig, T. Herbst, D. Rais and F. Seeler, Angew. Chem., Int. Ed., 2005, 44, 7461-7463; (n) S. Bertsch, H. Braunschweig, B. Christ, M. Forster, K. Schwab and K. Radacki, Angew. Chem., Int. Ed., 2010, 49, 9517-9520; (o) H. Braunschweig, M. Colling, C. Hu and K. Radacki, Angew. Chem., Int. Ed., 2003, 42, 205-208.

15 (a) According to the Cambridge Crystallographic Database, Version 5.35, Cambridge Crystallographic Data Centre, November 2013, http://www.ccdc.cam.ac.uk/data_request/ cif; (b) M. Ito, N. Tokitoh, T. Kawashima and R. Okazaki, Tetrahedron Lett., 1999, 40, 5557-5560; (c) M. Yalpani, R. Köster and R. Boese, Eur. J. Inorg. Chem., 1990, 123, 707-712.

16 M. Arrowsmith, D. Auerhammer, R. Bertermann, H. Braunschweig, G. Bringmann, M. A. Celik, R. D. Dewhurst, M. Finze, M. Grüne, M. Hailmann, T. Hertle and I. Krummenacher, Angew. Chem., Int. Ed., 2016, 55, 14464-14468. 